\title{
EFFECTS OF AIR POLLUTANTS ON
}

\section{AGRICULTURAL CROPS}

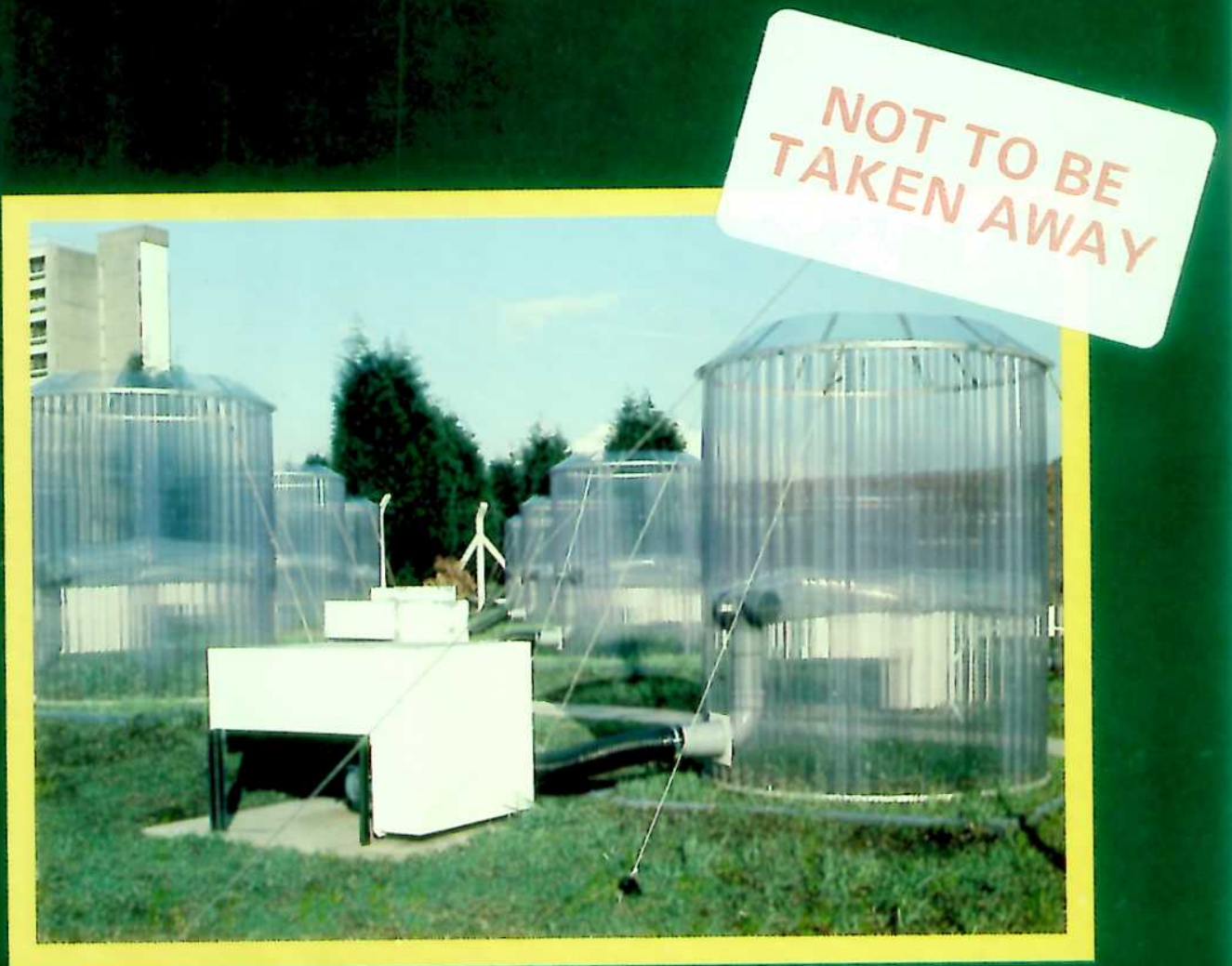

INSTITUTE OF TERRESTRIAL ECOLOGY NATURAL ENVIRONMENT RESEARCH COUNCIL 
f 


\section{INSTITUTE OF TERRESTRIAL ECOLOGY NATURAL ENVIRONMENT RESEARCH COUNCIL}

\section{EFFECTS OF AIR POLLUTANTS ON AGRICULTURAL CROPS}

F T Last, D Fowler Institute of Terrestrial Ecology Bush Estate Penicuik Midlothian EH26 OQB Scotland

and

P H Freer-Smith

Department of Biology

University of Ulster at Jordanstown

Shore Road Newtownabbey

Co Antrim BT37 0QB Northern Ireland 
Printed in Great Britain by

The Burlington Press (Cambridge) Ltd

Station Road, Foxton, Cambridge CB2 6SW

(C) NERC Copyright 1985

Published in 1985 by

Institute of Terrestrial Ecology

Administrative Headquarters

Monks Wood Experimental Station

Abbots Ripton

Huntingdon

PE17 2LS

ISBN 0904282902

\section{COVER ILLUSTRATIONS}

An 'open-top chamber' used for studying air pollution effects on the growth and yield of barley. Individual chambers are supplied with polluted ambient air, or air from which $\mathrm{SO}_{2}, \mathrm{NO}_{2}$ and $\mathrm{O}_{3}$ have been removed by filtration. (Photograph D Fowler)

The Institute of Terrestrial Ecology (ITE) was established in 1973, from the former Nature Conservancy's research stations and staff, joined later by the Institute of Tree Biology and the Culture Centre of Algae and Protozoa. ITE contributes to, and draws upon, the collective knowledge of the 14 sister institutes which make up the Natural Environment Research Council, spanning all the environmental sciences.

The Institute studies the factors determining the structure, composition and processes of land and freshwater systems, and of individual plant and animal species. It is developing a sounder scientific basis for predicting and modelling environmental trends arising from natural or man-made change. The results of this research are available to those responsible for the protection, management and wise use of our natural resources.

One quarter of ITE's work is research commissioned by customers, such as the Department of Environment, the European Economic Community, the Nature Conservancy Council and the Overseas Development Administration. The remainder is fundamental research supported by NERC.

ITE's expertise is widely used by international organizations in overseas projects and programmes of research.

Prof F T Last, Dr D Fowler

Institute of Terrestrial Ecology

Bush Estate, Penicuik

Midlothian EH26 0QB

Scotland

0314454343 and $\operatorname{Dr} \mathrm{PH}$ Freer-Smith

University of Ulster at Jordanstown

Shore Road, Newtownabbey

Co Antrim BT37 0QB

Northern Ireland

023165131 ext 2227 


\section{CONTENTS}

Summary

Page

1. The challenge 6

2. Introduction 6

3. The pollution climate $\quad 7$

$\begin{array}{ll}3.1 \text { The constituents } & 7\end{array}$

$\begin{array}{ll}3.1 .1 \text { Gaseous pollutants } & 7\end{array}$

3.1.2 Particulate pollutants $\quad 8$

3.2 Concentrations of the different gaseous constituents 8

$\begin{array}{ll}3.2 .1 \text { Spatial differences } & 9\end{array}$

3.2.2 Temporal differences 10

$\begin{array}{ll}3.2 .3 \text { Summary } & 11\end{array}$

3.3 Composition of acid rain sensu stricto 12

3.4 Effective dose $\quad 12$

4. Effects of atmospheric pollutants on plant growth in $\begin{array}{ll}\text { controlled conditions } & 14\end{array}$

4.1 Cellular and biochemical effects $\quad 14$

$\begin{array}{ll}\text { 4.1.1 Ozone }\left(\mathrm{O}_{3}\right) & 14\end{array}$

4.1.2 Sulphur dioxide $\left(\mathrm{SO}_{2}\right)$ and oxides of nitrogen $\left(\mathrm{NO}_{\mathrm{x}}\right)$

4.2 Effects of atmospheric pollutants on the macroscopic $\begin{array}{ll}\text { growth of plants } & 15\end{array}$

5. Influence of other biotic and abiotic factors on the responses of plants to atmospheric pollutants

6. Plant losses in field conditions attributable to atmospheric pollutants

$\begin{array}{ll}\text { 7. References } & 25\end{array}$ 


\section{SUMMARY}

1. It has been shown in closely controlled conditions that a range of atmospheric pollutants, including sulphur dioxide, oxides of nitrogen, ozone and fluorides, can affect the metabolism of plant cells and appreciably decrease macroscopic growth. Usually, plant performance is decreased, but small concentrations of sulphur dioxide and oxides of nitrogen can be beneficial.

2. For many years it was thought that growth decreases occurred only when foliage was visibly damaged (acute damage), but now it is recognized that growth decreases, including changes in root/shoot ratios, can occur in the absence of 'visible damage'.

3. The sensitivity or tolerance of different plant species to small concentrations of sulphur dioxide is not necessarily related to the responses of the same species to large concentrations. To extrapolate from one to the other, it is necessary to know the shape of the dose-response curves.

4. The sensitivity/tolerance of plants to pollutants cannot be assumed to be the same at all stages of development.

5. In controlled conditions, it has been found that the effects of mixtures can be (i) less ('antagonistic') than the sum of the effects of the gases tested separately, (ii) equal ('additive') to the sum of the effects of the gases when tested separately, or (iii) greater ('synergistic').

6. With an increasing awareness of the factors affecting plant responses, including the effects of weather (notably frost), what can be said about the reactions of plants to the concentrations that are now found in the field, recognizing that pollutants usually occur in mixtures in which the concentrations of the different constitutents are varying diurnally and seasonally?

7. In experiments using open-top chambers supplied with ambient or filteredambient air, it has been found that the removal of pollutants, by filtration, enabled greater plant growth. When an atmosphere containing appreciable amounts of ozone was filtered, yields of the ozone-sensitive snap bean cultivar BBL 290 were increased by $15 \%$ (average of 5 years). Grain yields of springsown barley were $32 \%$ larger in chambers supplied with filtered air than in 
chambers with unfiltered air with $18-22 \mathrm{ppbV}^{*} \mathrm{SO}_{2}$ and $1.0 \mathrm{ppbV}$ hydrogen fluoride.

8. While these observations may give an indication of losses occurring in field conditions, more needs to be known about the influence of open-top chambers on the sensitivity of plants to pollutants.

9. To obtain estimates of losses on a regional scale, assessments must be made at a larger range of locations with different ambient mixtures of pollutants. For these locations to be selected rationally, existing knowledge of sulphur dioxide concentrations must be augmented by records of oxides of nitrogen and ozone.

10. As yet, there is no unequivocal evidence showing that agricultural crops, growing in the field in Europe, are damaged directly or indirectly by realistic amounts of acid rain (sensu stricto).

11. Although agricultural soils are sensitive to acid rain, the effects of acid rain on soils are small compared to the acidifying effects of intensive cropping which have been mitigated traditionally by the application of lime.

"parts in $10^{9}$ by volume 


\section{THE CHALLENGE}

Many atmospheric pollutants have been shown to affect plant growth, usually deleteriously, in controlled conditions, but what is the extent of damage in the field, recognizing that, since the introduction of the Clean Air Acts, the emphasis has switched from large, and usually local, concentrations causing obvious blemishes (acute damage), eg leaf necroses, to smaller and widespread loads of atmospheric pollutants which may be adversely affecting plant performance without the development of conspicuous blemishes (chronic damage)?

\section{INTRODUCTION}

Why is it that we are still unable to estimate, within reasonable limits, the damage being done to crops by atmospheric pollutants, bearing in mind the research effort already expended? Progress has undoubtedly been delayed by the absence of the pollution equivalents of insecticides and fungicides, the tools used by plant pathologists to exclude pests and pathogens. More fundamentally, most pollution research has been based on a less than adequate knowledge of the occurrence of atmospheric pollutants. *

In taking stock of our present knowledge of the effects of atmospheric pollutants on agricultural crops and other short-lived vegetation, it is appropriate to be reminded of the postulates enunciated in 1891 by Koch, an eminent German pathologist. Koch's postulates are a set of criteria for characterizing disease:

1. The suspected causal organism/s must be constantly associated with the disease.

2. The causal organism/s must be isolated and identified.

3. When inoculated into a healthy plant, the causal organism/s must reproduce the original disease.

If the third postulate is rewritten to suit the needs of pollution research -

Pollutants used to fumigate healthy plants must reproduce the original disease,

- the postulates provide a useful experimental framework which has been wastefully ignored (Last et al. 1984) They require a clear understanding of the nature of the causal agent/s, in this instance the pollution climate.

"At $25^{\circ} \mathrm{C}$ and $101.3 \mathrm{kPa}$,

$1 \mathrm{ppbV}$ sulphur dioxide $=2.67 \mu \mathrm{g} \mathrm{SO}_{2} \mathrm{~m}^{-3}$

1 ppbV nitric oxide $\quad=1.25 \mu \mathrm{g} \mathrm{NO} \mathrm{m}^{-3}$

$1 \mathrm{ppbV}$ nitrogen dioxide $=1.91 \mu \mathrm{g} \mathrm{NO}_{2} \mathrm{~m}^{-3}$

1 ppbV ozone

$=2.00 \mu \mathrm{g} \mathrm{O}_{3} \mathrm{~m}^{-3}$ 


\section{THE POLLUTION CLIMATE}

\subsection{The constituents}

Crop plants and vegetation can be exposed to a variety of gaseous and particulate pollutants, usually occurring in mixtures.

\subsubsection{Gaseous pollutants}

Two categories can be identified, primary and secondary. The former are released directly into the atmosphere, the amounts released, by the activities of man, often augmenting naturally occurring concentrations.

Thus, industrial emissions of $\mathrm{SO}_{2}$ augment concentrations of naturally occurring $\mathrm{SO}_{2}$ mostly formed by the oxidation of gaseous sulphides. The other group, of secondary pollutants, owes its origin to chemical reactions within the atmosphere involving, at least in part, some of the primary pollutants.

i. Primary gaseous pollutants (including $\mathrm{SO}_{2}, \mathrm{NO}_{2}, \mathrm{NO}, \mathrm{NH}_{3}, \mathrm{HF}, \mathrm{CO}$, $\mathrm{CO}_{2}$, hydrocarbons, etc) $\mathrm{SO}_{2}$ results from the combustion of sulphurcontaining fossil fuels and the smelting of sulphur-containing ores. In contrast, $\mathrm{NO}$ and $\mathrm{NO}_{2}$ are primarily formed from atmospheric nitrogen which is oxidized at the high temperatures generated by a wide range of industrial processes. Carbon dioxide and monoxide are

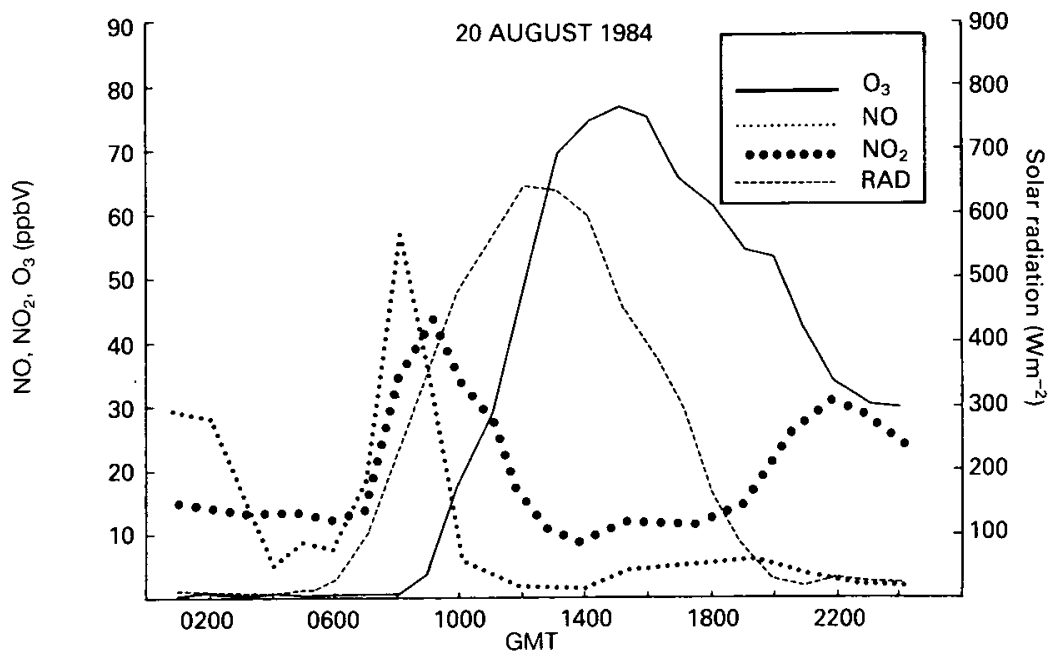

Figure 1.

The sequential occurrence of peak concentrations of nitric oxide $(\mathrm{NO})$, nitrogen dioxide $\left(\mathrm{NO}_{2}\right)$ and ozone $\left(\mathrm{O}_{3}\right)$ at an urban site in central Scotland during a photochemical episode on 20 August 1984. (RAD = solar radiation) 
released when fossil fuels are consumed, the former $\left(\mathrm{CO}_{2}\right)$ occurring when combustion is efficient, the latter $(\mathrm{CO})$ occurring when combustion is less efficient, as is the case with motor vehicles. Hydrogen fluoride can be traced, in the main, to the electrolytic smelting of cryolite, an aluminium ore, and to the emissions from brickworks.

ii. Secondary gaseous pollutants Strictly speaking, $\mathrm{NO}_{2}$ should be classified as a secondary pollutant as it is mostly formed by the oxidation of primary NO.

Of the substances more generally regarded as secondary, attention is usually attuned to ozone, which in the troposphere has at least 2 sources: (a) the stratosphere where, at altitudes of $20 \mathrm{~km}$ or more, ozone is formed following the photolysis of molecular oxygen, and (b) the troposphere itself where it is produced as a result of photochemical reactions involving oxides of nitrogen and hydrocarbons, and sometimes leading to photochemical smogs with, among other constituents, peroxyacetyl nitrate (PAN) (Figure 1).

\subsubsection{Particulate pollutants}

As with gaseous pollutants, there are primary and secondary forms. The former include emissions from industrial installations and vehicles with releases of a variable assortment of heavy metals. The latter include the aerosol particles generated within the atmosphere from gas phase oxidation of $\mathrm{SO}_{2}$ and $\mathrm{NO}_{2}$ to sulphuric and nitric acids respectively. Sulphuric acid particles are formed directly in this process, whereas nitric acid may be present as a vapour or a particle. Subsequently, some of these particles react with atmospheric ammonia to form ammonium sulphate and ammonium nitrate ... aerosols with particles typically ranging in size from 0.1 to $1.0 \mu \mathrm{m}$ (diam).

\subsection{Concentrations of the different gaseous constituents}

When considering the effects of pollutants, it is not helpful to consider only the mean concentrations over large regions. Those of $\mathrm{SO}_{2}$, ozone, etc, have little relevance to the concentrations 'experienced' by plants growing in rural areas. Instead, it is more useful to examine separately the atmospheric concentrations of pollutants in urban areas and in rural areas near to, or at a distance from, significant conurbations. 


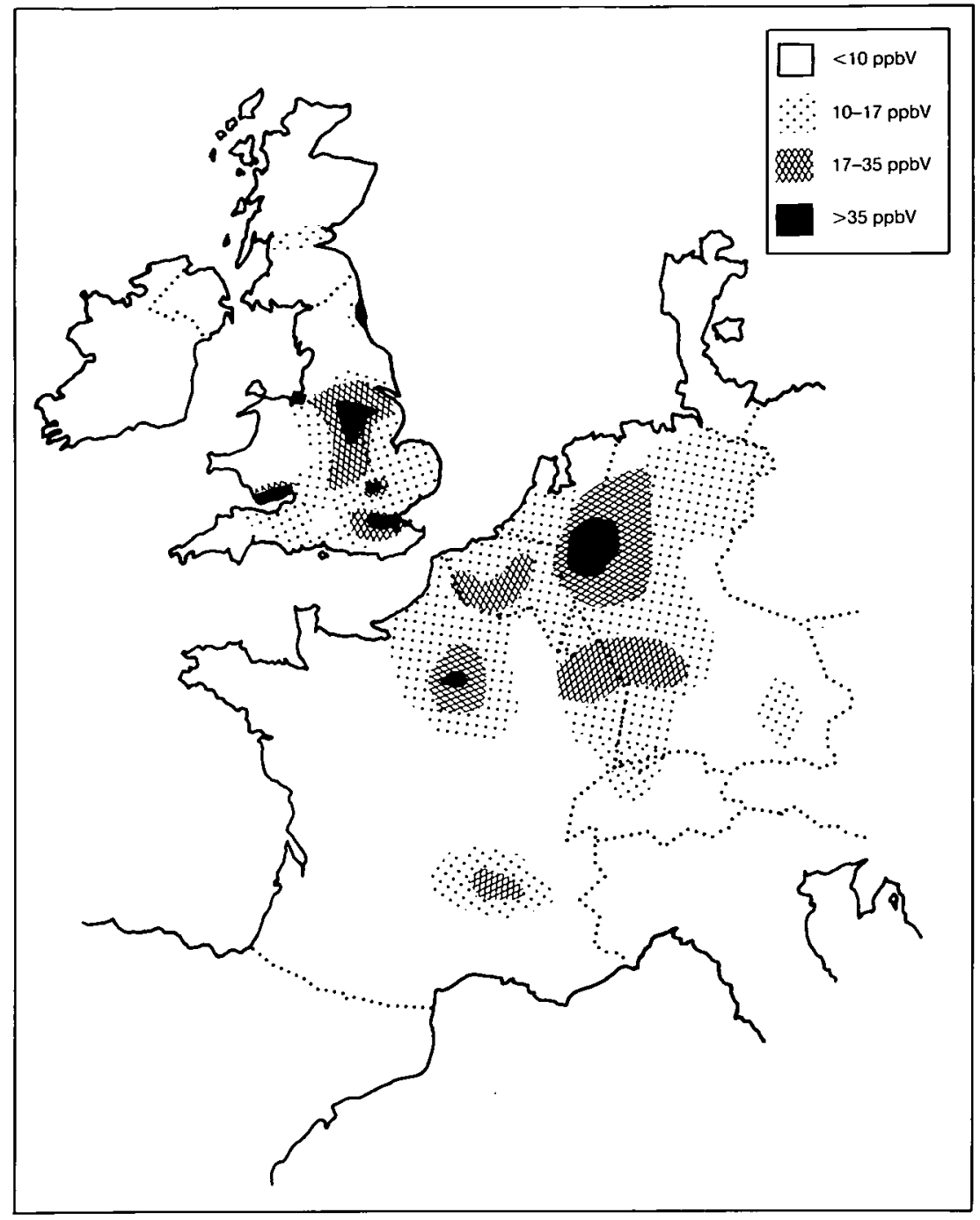

Figure 2.

Annual mean atmospheric concentrations of sulphur dioxide over western Europe in 1974, showing relatively large concentrations over the industrial midlands of England, the London conurbation, the Ruhr and industrial northern France (Fowler \& Cape 1982)

\subsubsection{Spatial differences (Figure 2)}

i. Urban areas Annual mean concentrations of $\mathrm{SO}_{2}$ and $\mathrm{NO}_{x}$ are typically in the range $20-50 \mathrm{ppbV}$, with $\mathrm{NO}_{x}$ consisting of more or 
less equal amounts of $\mathrm{NO}$ and $\mathrm{NO}_{2}$. Annual means are not particularly useful for ozone as they are generally dominated by 'background' ozone filtering downwards from the stratosphere. Instead, it is probable that a better biological indicator can be gained from the numbers of days in which maximum ozone concentrations exceed $60 \mathrm{ppbV}$ ('natural' concentrations seldom exceed $40 \mathrm{ppbV}$ at low elevations). In western Europe, the numbers of days with ozone concentrations exceeding $60 \mathrm{ppbV}$, which are greatly influenced by meteorological conditions, range from 5 to 50 per year with peak concentrations typically of $100 \mathrm{ppbV}$. In eastern North America, peak ozone concentrations are generally larger, the occurrence of ozone days ( $>60$ ppbV) possibly exceeding that in Europe by a factor of 2 . Concentrations of ammonia and hydrogen fluoride are usually very small, less than 10 and $1 \mathrm{ppbV}$ respectively. Like the amounts of ozone, the concentrations of particulates are very variable, ranging from 10 to $100 \mu \mathrm{g} \mathrm{m}^{-3}$, concentrations that may be significantly exceeded in urban areas during temperature inversions.

ii. Rural areas near significant conurbations Annual mean concentrations of $\mathrm{SO}_{2}$ and $\mathrm{NO}_{x}$ are likely to range from 2 to $30 \mathrm{ppbV}$, with $\mathrm{NO}_{2}$ accounting for $80 \%$ of the $\mathrm{NO}_{x}$. While mean concentrations of particulate material range between 2 and $30 \mu \mathrm{g} \mathrm{m}^{-3}$, the number of days during which ozone concentrations will exceed $60 \mathrm{ppbV}$ is likely to be the same as in urban areas, namely 5 to 50 per year. In rural areas near to Edinburgh, Scotland, the number of 'ozone days' has ranged between 15 and 20 per year, while the amount of $\mathrm{SO}_{4}^{2-}$ in particulate matter averages about $6 \mu \mathrm{g} \mathrm{SO} \mathrm{S}_{4}^{2-} \mathrm{m}^{-3}$.

iii. Rural areas distant from significant conurbations Recognizing that the data have a large degree of uncertainty - in how many countries have positive attempts been made to monitor the rural environment systematically? - it seems reasonable to suggest annual mean $\mathrm{SO}_{2}$ and $\mathrm{NO}_{x}$ concentrations of $0.1-10$, and $0.2-10 \mathrm{ppbV}$ with 5 to 50 ozone days per year. The concentrations of particles are unlikely to differ significantly from those recorded in rural areas near major conurbations.

\subsubsection{Temporal differences}

Observations, in a lightly polluted area of Scotland with a mean annual $\mathrm{SO}_{2}$ concentration of about $11 \mathrm{ppbV}$, have shown that concentrations of $\mathrm{SO}_{2}$ are maximal about 10.00 GMT and minimal at 15.00-18.00 GMT. Further, it was found that concentrations were larger in the winter than the summer. In other words, 'mean concentrations' erroneously tend to 
present the idea of an unchanging concentration of pollutant. Instead, there are predictable and systematic variations which may be of great importance when related to the seasonal development of plants.

In Scotland, the amounts of $\mathrm{SO}_{2}$ were matched by similar mean concentrations of oxides of nitrogen and, like those of $\mathrm{SO}_{2}$, they varied diurnally and seasonally, the seasonal maximum and minimum occurring in November/December and May/June respectively. While the patterns of diurnally and seasonally changing concentrations of $\mathrm{SO}_{2}$ and $\mathrm{NO}_{2}$ were not too dissimilar, those of ozone were markedly different (Figure 3). Daily concentrations of ozone were maximal at about $15.00 \mathrm{GMT}$ and minimal at $08.00 \mathrm{GMT}$, its seasonal concentrations being predictably largest from April to June and minimal in December/January.

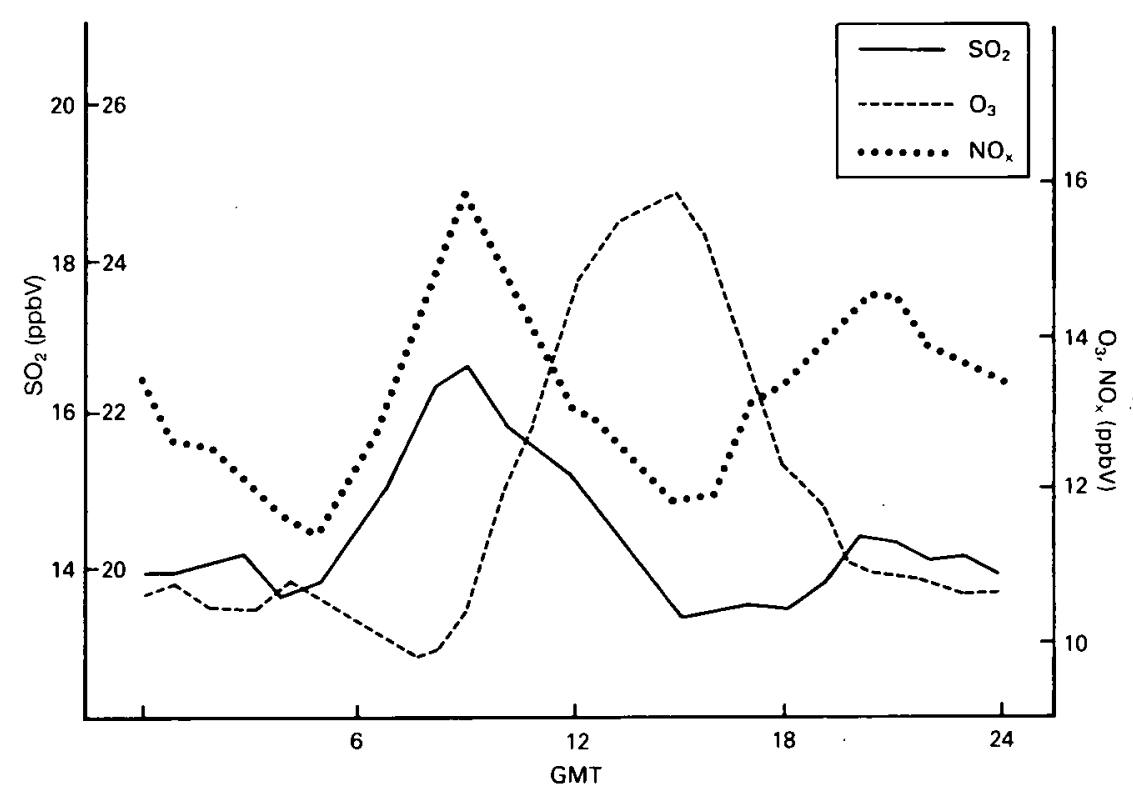

Figure 3.

The diurnally changing concentrations of sulphur dioxide $\left(\mathrm{SO}_{2}\right)$, oxides of nitrogen $\left(\mathrm{NO}_{x}\right)$ and ozone $\left(\mathrm{O}_{3}\right)$ in the atmosphere above a coniferous forest in central Scotland where the annual average $\mathrm{SO}_{2}$ concentration is $11 \mathrm{ppbV}$ (Fowler \& Cape 1982)

\subsubsection{Summary}

While accepting that details will vary from one location to another, and from one country to another, the simple statement that the atmosphere 
has an average mean $\mathrm{SO}_{2}$ concentration of $11 \mathrm{ppbV}$ implies that vegetation is likely to be subject to daily and seasonally varying mixtures of $\mathrm{SO}_{2}, \mathrm{NO}_{x}$ and ozone, and probably other substances, with the changes in concentrations of the different substances occurring at different times of the day and year. Doubtless the picture will differ in different habitats, with $11 \mathrm{ppbV}$ of $\mathrm{SO}_{2}$ in Czechoslovakia implying something quite different from $11 \mathrm{ppbV} \mathrm{SO}_{2}$ in Canada.

\subsection{Composition of acid rain sensu stricto}

Much of what has been written about the changing concentrations of gaseous pollutants is equally applicable, in principle, to acid rain. Natural sources of sulphur, nitrogen and chlorine containing gases produce annual average acidities in rain of about $\mathrm{pH}$ 5.0. This degree of acidity is not greatly exceeded on the north-western periphery of Europe, but it increases by almost a factor of 10 to values around $\mathrm{pH} 4.0$ over the eastern Netherlands and the Ruhr. These mean values conceal a systematic seasonal cycle, in which rain in northern Britain and Scandinavia is more acid in April, May and June than at other times of the year. They also conceal a significant spread in the amounts of acidity in different rain events. Thus, the acidity of individual events at a location with rain having, over a period of 5 years, a mean $\mathrm{pH}$ of 4.2 ranged from 2.9 to 7.0 (Fowler \& Cape 1984).

\subsection{Effective dose}

It is one thing to know the concentrations of pollutants in the atmosphere, but what are the effective doses experienced by plants? Atmospheric pollutants are transferred to surfaces by 2 processes:

i. dry deposition - the direct transfer of gases and particles on to terrestrial surfaces;

ii. wet deposition - an indirect process whereby particulate and gaseous pollutants are transferred to the surface in or on raindrops, snowflakes or hailstones.

Dry deposition is strongly influenced by 2 sets of resistances: atmospheric and surface. Of these, the surface resistances are usually appreciably larger than the atmospheric resistances, the difference being larger in tall, aerodynamically rough crops in which atmospheric resistances are relatively small. The surface resistances in a crop contain 4 components, attributable to stomata, leaf surfaces, the occurrence of surface water and soil (Fowler 1984). Of these, stomatal resistances are quantitatively the most important, as stomata are the main sites for the uptake of $\mathrm{SO}_{2}, \mathrm{NO}_{2}$ and ozone. For this reason, the effective dose is likely to relate to the atmospheric concentrations during daylight hours when plants are likely to be photosynthesizing actively with their stomata open. 
Thus, the effective dose of a pollutant, or a mixture of pollutants, can be envisaged as the concentration/s occurring during daylight hours and, as a result, there is a strong argument to focus not on seasonal or $24 \mathrm{~h}$ mean concentrations, but on those occurring during daytime (Fowler \& Cape 1982). This consideration was taken into account, for instance, when Heck et al. (1982) planned their series of ozone fumigations in open-top chambers, an integral part of the National Crop Loss Assessment Network established in the United States.

In thinking about acid rain sensu stricto, it seems that the 'extreme' acid events are likely to be of greater biological significance than rain at, or near, the mean $\mathrm{pH}$. For this reason, the 'effective dose' should be attuned to the distribution of the more acid events, a suggestion hinting at the possible part played by 'occult' precipitation, the precipitation attributable to capture of mist and fog droplets by vegetation. Whereas 'normal' acid rain seems to have a relatively small direct effect on plant growth, it is possible that the much more acidic occult precipitation may be harmful, as has been suggested, when it occurs with significant concentrations of ozone.

Whereas evidence concerned with effects on forest soils indicates that the acidity of some forest soils in southern Sweden and the Federal Republic of Germany has sometimes increased by as much as one $\mathrm{pH}$ unit, during the last 50 years, theory suggests that changes of this magnitude are unlikely in agricultural soils which are intensively managed. In these soils, inputs of sulphur and nitrogen pollutants may act as plant nutrients: their acidifying influences are, however, likely to be minimized or eliminated by the repeated applications of lime needed to neutralize the acidifying effects of successive crops and their fertilizer soil amendments. 


\section{EFFECTS OF ATMOSPHERIC POLLUTANTS ON PLANT GROWTH IN CONTROLLED CONDITIONS}

Times have changed. Twenty years ago, interest centred on obvious blemishes, leaf chloroses and necroses, the loss of foliage and plant death - the occurrence of these symptoms (acute damage) having been described in many reviews. Now, however, attention is focused on growth alterations in the absence of blemishes (chronic damage) - pollutants can affect quality in addition to quantity, vide the smaller concentrations of protein in the yield of acid rain-treated Amsoy 71 soya beans (Evans et al. 1984).

\subsection{Cellular and biochemical effects}

These are determined by the concentration of pollutants in the atmosphere, their solubilities in water and their reactivities within plants (see Koziol \& Whatley 1984).

\subsubsection{Ozone $\left(\mathrm{O}_{3}\right)$}

This pollutant is very reactive and strongly affects plasma and organelle membranes (Heath 1980). Although it is clear that a fraction of the pollutant ozone reacts with intracellular components such as glutathione, and functional groups of proteins (Mudd et al. 1984), the mode of action of ozone has not been fully resolved - are the proteins or lipids of the plasma membranes oxidized preferentially? However, the deleterious effects of ozone on membrane function and the formation of ATP in phosphorylation are not in dispute (Heath 1980).

\subsubsection{Sulphur dioxide $\left(\mathrm{SO}_{2}\right)$ and oxides of nitrogen $\left(\mathrm{NO}_{\mathrm{x}}\right)$}

Some of the aqueous dissociation products of these pollutants are 'normal' plant metabolites and, consequently, they may be expected in some circumstances to act as sources of nutrient sulphur and nitrogen.

i. Sulphur dioxide Soluble in water, it dissolves to form $\mathrm{SO}_{2}$ (aqueous), which establishes equilibria with its dissociation products bisulphite $\left(\mathrm{HSO}_{3}^{-}\right)$and sulphite $\left(\mathrm{SO}_{3}^{2-}\right)$ ions. Sulphite formed in this way may be oxidized to sulphate $\left(\mathrm{SO}_{4}^{2-}\right)$ and metabolized by the sulphate reduction pathway (Ziegler 1975). Damage from exposure to $\mathrm{SO}_{2}$ occurs when unusually large concentrations of the intermediate oxidation products accumulate in tissue, eg when their rates of production exceed the ability of plants to incorporate sulphur by the sulphate reduction pathway. Large accumulations can result in cell death (a form of acute injury), but smaller amounts are associated with temporary metabolic disturbances, which include reversible changes in net photosynthesis, photorespiration, translocation, en- 
zyme activities and amounts of ATP (Black \& Unsworth 1979; Koziol 1984; Wellburn 1982, 1984). Because the effects on photosynthesis have been emphasized, chloroplasts have been considered as the main 'sites of action'. The $\mathrm{pH}$ within plastids favours the formation of sulphite ions which are commonly regarded as the toxic product of $\mathrm{SO}_{2}$ in aqueous solutions (Ziegler 1975) but in many experiments $\mathrm{SO}_{2}$ (gas or aqueous) is the toxic agent (Cape 1984). Wellburn (1982) produced a scheme summarizing the features of chloroplast function (and the processes dependent upon those functions) which may be influenced by $\mathrm{SO}_{2}$ and $\mathrm{NO}_{x}$. If $\mathrm{SO}_{2}$ (also $\mathrm{NO}_{x}$ and $\mathrm{O}_{3}$ ) and its products influence electron flow by damaging membranes or inhibiting phosphorylation, then rates of protein and starch synthesis and carbon dioxide $\left(\mathrm{CO}_{2}\right)$ fixation would be decreased. In addition to the direct effects on enzymes, such as those which are concerned in the Calvin cycle (Parry \& Whittingham 1984), the increased acidity attributable to ions from pollutant $\mathrm{SO}_{2}$ (and $\mathrm{NO}_{x}$ ) may affect stromal reactions.

ii. Oxides of nitrogen ( $\mathrm{NO}$ and $\mathrm{NO}_{2}$ collectively designated $\mathrm{NO}_{x}$ ) Nitrogen dioxide $\left(\mathrm{NO}_{2}\right)$ and nitric oxide (NO), are not very soluble in water. However, because of its more than expected rate of uptake by plants, the entry of $\mathrm{NO}$ into cells seems to be sustained by oxidation to $\mathrm{NO}_{2}$ and by reactions in extracellular water which enhance its apparent solubility (Mansfield \& Freer-Smith 1981). Within leaves, oxides of nitrogen dissolve in cellular fluids and as a result the increased acidity, or increased concentrations of nitrite ions, may be associated with damage. Normally, nitrate ions are converted by nitrate reductase to nitrite, and then from nitrite to ammonia by nitrite reductase.

Zeevart $(1974,1976)$ found enhanced nitrate reductase activity in pea seedlings exposed to $\mathrm{NO}_{2}$, while Wellburn (1982) detected increased activity of nitrite reductase in pasture grasses and tomatoes when similarly exposed. However, when $\mathrm{SO}_{2}$ is added, to give a mixture of $\mathrm{NO}_{2}$ and $\mathrm{SO}_{2}$, it seems that some grass cultivars are unable to increase their nitrite reductase activities. As a result, the consequential accumulations of nitrite may be responsible for augmenting the damage done by $\mathrm{SO}_{2}$ - an effect now being commonly reported. This effect may also be attributed to the initiation of free radical reactions.

\subsection{Effects of atmospheric pollutants on the macroscopic growth of plants}

Until the 1970s attention tended to be focused on acute damage which is now much more restricted. Attempts were made to rank the sensitivities of plants, annual, biennial and perennial, on the basis of acute damage, and, despite the 
varying locations at which the different observations were made in the northern temperate region, the rankings obtained were surprisingly consistent, with maize, celery and rape being consistently regarded as 'tolerant', while rye, rye-grass and radish were regarded as 'sensitive'. These rankings, based on performance in the field, were often tacitly assumed to reflect plant responses to sulphur without fully appreciating that the atmosphere usually contained mixtures of pollutants, a feature emphasized by the analysis made by Mansfield and Freer-Smith (1981). Others have shown that the responses of plants to large concentrations of $\mathrm{SO}_{2}$ are not good indicators of the damage that may be done by smaller concentrations. Using an example from the forestry literature, it seems that Sitka spruce (Picea sitchensis) is more sensitive than Norway spruce (Picea abies) to small concentrations of $\mathrm{SO}_{2}$, whereas the latter is the more sensitive to larger concentrations. However, most of our knowledge of sensitivity/tolerance is related to ambient atmospheres in which $\mathrm{SO}_{2}$ and $\mathrm{NO}_{2}$ predominated: much less is known about sensitivity to ozone, although it seems that leguminous plants (species of Medicago, Pisum and Trifolium) are fairly consistently sensitive (Table 1).

Table 1.

Ozone sensitivities of crops grown in the UK, based on visible injury following exposure of the crops to $250 \mathrm{ppbV} \mathrm{O}_{3}$ for 4 hours in standard environmental conditions (Ashmore 1984)

Very sensitive

White clover (Trifolium repens)

Red clover (Trifolium pratense)

Pea (Pisum sativum)

Lucerne (Medicago sativus)

Spinach (Spinacia oleracea)

Radish (Raphanus sativus)

Vine (Vitis vinifera)

Hop (Humulus hupulus)

Broccoli (Brassica oleracea var. Italica)

Timothy (Phleum pratense)

Slightly sensitive

Wheat (Triticum aestivum)

Rye (Secale cereale)

Fescue (Festuca spp.)

Italian rye-grass (Lolium multiflorum)

Perennial rye-grass (Lolium perenne)

Potato (Solanum tuberosum)

Beetroot (Beta vulgaris var. Esculenta)

Leek (Allium porrum)

Swede (Brassica rutabaga)

Turnip (Brassica rapa)

\author{
Moderately sensitive \\ Barley (Hordeum vulgare) \\ Cock's-foot (Dactylis glomerata) \\ Tomato (Lycopersicon esculentum) \\ Oats (Avena sativa) \\ Maize (Zea mays) \\ Carrot (Daucus carota) \\ Onion (Allium cepa) \\ Parsnip (Pastinaca sativa) \\ Broad bean (Vicia faba) \\ French bean (Phaseolus vulgaris) \\ Resistant \\ Sugar beat (Beta vulgaris) \\ Oilseed rape (Brassica napus) \\ Mangold (Beta vulgaris) \\ Kale (Brassica oleracea var. Acephala) \\ Brussel sprouts (Brassica oleracea var. \\ Gemmifera) \\ Lettuce (Lactuca sativa) \\ Cabbage (Brassica oleracea var. Capitata) \\ Cauliflower (Brassica oleracea var. Botrytis)
}

There are now several published reports of the effects of prolonged exposures to 'realistic' concentrations of either $\mathrm{SO}_{2}$ or ozone. The many experiments 
done with pasture grasses indicate that sizes of yield losses, attributable to $\mathrm{SO}_{2}$, depend upon pollutant concentrations, the species and cultivars of pasture grasses, their stage of development when exposed (Figure 4), and environmental conditions (Figure 5).

Growth decreases and accelerated senescence have been recorded with mean $\mathrm{SO}_{2}$ concentrations less than $37 \mathrm{ppbV}$. Jacobson (1982), in reviewing the effects of ozone, has indicated that this pollutant can decrease growth. In both series of experiments, however, there has been an increasing emphasis on the partitioning of assimilates (dry matter) and, in common, they show greater adverse effects on root growth than on tops - a feature of probable significance when considering the effects of pollutants on crops growing in different environments. Because of the greater damage to roots, plants exposed to $\mathrm{SO}_{2}$ and $\mathrm{O}_{3}$ may be at more risk in dry, than in moist, soils.

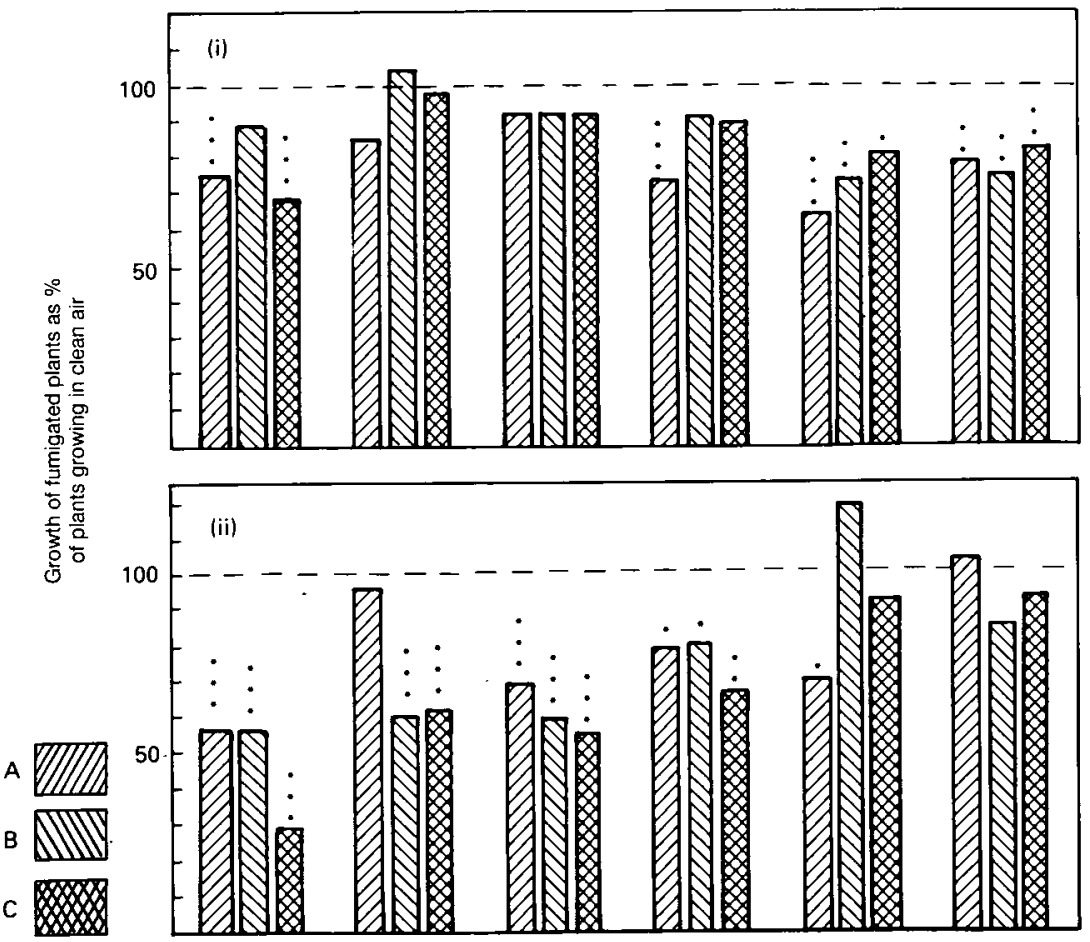

Figure 4.

Observations among grasses indicating the effects of $\mathrm{A} . \mathrm{SO}_{2}, \mathrm{~B} . \mathrm{NO}_{2}$, or C. the combination of $\mathrm{SO}_{2}+$ $\mathrm{NO}_{2}$ on plants (i) grown in clean air for 42 days prior to pollutant exposure, or (ii) grown in polluted air from emergence (Whitmore \& Mansfield 1983) 


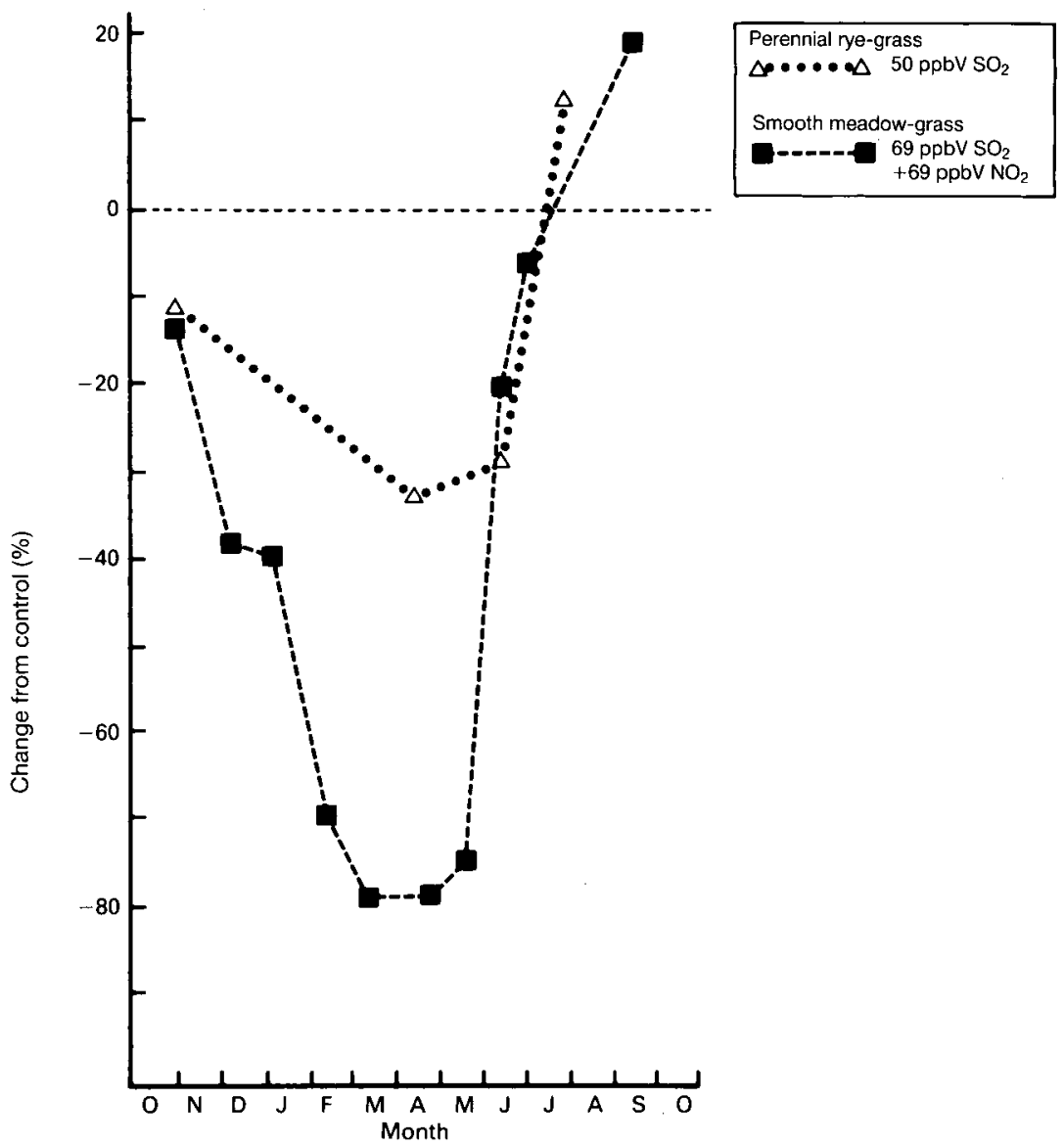

Figure 5.

Effects of time of year on the effects of $50 \mathrm{ppbV}$ sulphur dioxide and $69 \mathrm{ppbV}$ each of sulphur dioxide and nitrogen dioxide on the growth of perennial rye-grass (Colvill et al. 1983) and smooth meadowgrass (Whitmore \& Mansfield 1983) respectively (after Roberts 1984)

Although fewer experiments have been done, it seems that plants are less sensitive to $\mathrm{NO}$ and $\mathrm{NO}_{2}$ than they are to $\mathrm{SO}_{2}$ or ozone (Amundson \& Maclean 1982). When smooth meadow-grass (Poa pratensis) was exposed to $\mathrm{NO}_{2}$ or $\mathrm{SO}_{2}$ (both at $62 \mathrm{ppbV}$ ), it was found that growth was decreased by both pollutants, but that root to shoot ratios were altered by $\mathrm{SO}_{2}$ alone. This alteration was exacerbated when meadow-grass was fumigated with a mixture of $\mathrm{SO}_{2}$ and $\mathrm{NO}_{2}$. 
There has been an increasing awareness of the interplay between different pollutants as has been shown in successive reviews (Reinert et al. 1975; Mansfield \& Freer-Smith 1981; Bell 1982). The effects of mixtures can be (i) less ('antagonistic') than the sum of the effects of the gases tested separately, (ii) equal ('additive') to the sum of the effects of the gases when tested separately, or (iii) greater ('synergistic'). In general, the effects of equal mixtures of $\mathrm{SO}_{2}$ and $\mathrm{O}_{3}$ are either 'antagonistic' or 'additive', although, when using concentrations of the different gases below those required to cause damage when tested separately, Ormrod (1982) found that the effects of $\mathrm{SO}_{2}$ and $\mathrm{O}_{3}$ were larger ('synergistic'). Ashmore and Onal (1984) also detected 'antagonistic' effects when spring barley was fumigated with mixtures containing 3 times as much ozone ( $180 \mathrm{ppbV}$ ) as $\mathrm{SO}_{2}$ (65 ppbV). However, when testing concentrations of the different gases, below those individually required to cause damage, Ormrod (1982) found that the effects of $\mathrm{SO}_{2}$ and $\mathrm{O}_{3}$ were larger than expected ('synergistic').

There are reports indicating that plant growth is sometimes increased when plants are grown in atmospheres with small amounts of pollutant $\mathrm{SO}_{2}$ or $\mathrm{NO}_{2}$. As crops are now more likely to suffer sulphur deficiency because of crop intensification and the substitution of ammonium sulphate by ammonium nitrate and urea, and potassium sulphate by potassium chloride, it has been suggested that the deposition (wet and dry) of sulphur pollutants may help satisfy the sulphur requirements of crops (Cowling \& Koziol 1982; Roberts et al. 1983). Cowling et al. (1973) found that the growth of perennial rye-grass in a soil with inadequate amounts of sulphate was increased by non-toxic concentrations of $\mathrm{SO}_{2}$. Anderson and Mansfield (1979) found that glasshouse-grown tomatoes could tolerate, and even benefit from, nitric oxide at concentrations less than $400 \mathrm{ppbV}$.

Thus, there is evidence, which needs to be corroborated in the field, to suggest that small concentrations of a variety of pollutants may aid plant growth. Dose-response relationships might, therefore, be expected to depict stimulation at small concentrations of pollutants, with a fairly rapid change, as concentrations increase, to a phytotoxic 'mode'.

In differing ways, Evans et al. (1983), Heck et al. (1982) and Roberts (1984) have attempted to establish the relationships between yield loss and dose for acid rain, ozone and $\mathrm{SO}_{2}$ respectively. While Evans et al. (1983), like Jacobson and Troiano (1983), have not obtained unequivocal evidence that seed yield decreases with increasing acidity (of simulated rain), they have indications of decreased yields of protein in the seeds of soya beans whose foliage was repeatedly wetted with rain at $\mathrm{pH} 2.7$ in addition to being exposed to ambient rain: this effect did not occur with simulated rain at $\mathrm{pH}$ 3.3. 
By pooling data from many different experiments with perennial rye-grass Roberts (1984) found the following relation:

$$
Y=7.33-0.21 X
$$

where $Y=$ percentage yield loss and $X=\mathrm{SO}_{2}$ concentration in ppbV.

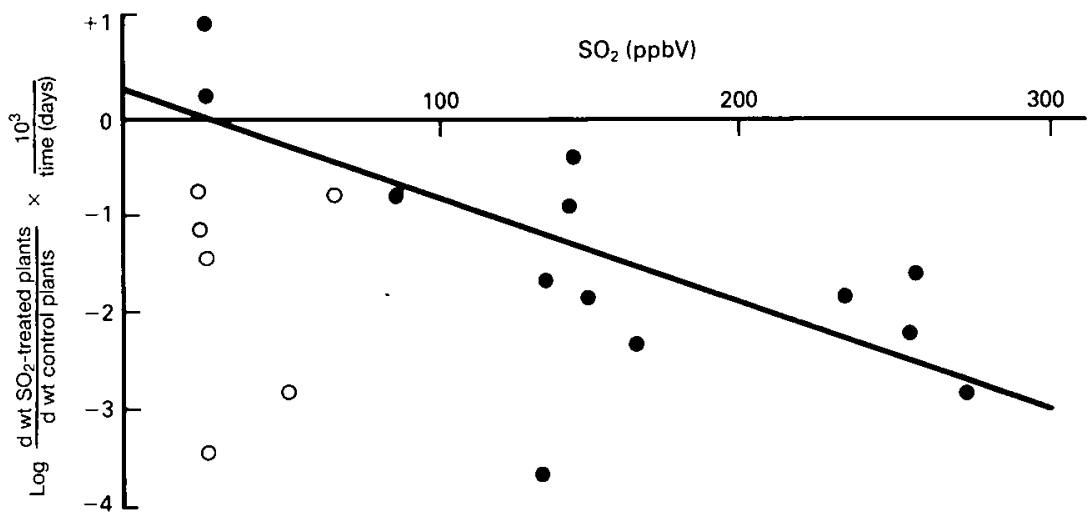

Figure 6.

The growth of perennial rye-grass in $\mathrm{SO}_{2}$-'free' atmospheres, compared with that in atmospheres with different mean concentrations of $\mathrm{SO}_{2}$. $\bullet$, growth when $\mathrm{SO}_{2}$ was added to filtered air; $\circ$, growth in unfiltered air with $\mathrm{SO}_{2}$ (after Mansfield \& Freer-Smith 1981)

In addition to showing that yields were decreased when rye-grass was grown in atmospheres with more than $40 \mathrm{ppbV}$, this equation indicates that yield (dry matter) increases, possibly significant, occurred in atmospheres with less than $30 \mathrm{ppbV} \mathrm{SO} \mathrm{S}_{2}$. However, Mansfield and Freer-Smith (1981) had earlier separated the available data into 2 batches, one concerned with the effects of $\mathrm{SO}_{2}$ added to pre-filtered air and the other relating to growth in ambient atmospheres with different amounts of $\mathrm{SO}_{2}$ (Figure 6). While they agree that $20-40 \mathrm{ppbV} \mathrm{SO}_{2}$ may increase rye-grass growth in otherwise clean air, these amounts in ambient mixtures were associated with appreciable decreases. The concurrent presence of other pollutants was suggested as the reason for the greater than expected phytotoxicity of $\mathrm{SO}_{2}$ in unfiltered ambient atmospheres. As a result, the inter-relationships between $\mathrm{SO}_{2}$ and $\mathrm{NO}_{2}$ have now been determined in greater detail. Whitmore (1985) exposed smooth meadow-grass for 38 days to mixtures containing 40,70 or $100 \mathrm{ppbV}$ of each of $\mathrm{SO}_{2}$ and $\mathrm{NO}_{2}$. The effects on plant dry weights were critically related to the products of exposure concentra- 
tions and duration. Although small doses sometimes stimulated growth, the transition from beneficial to deleterious effects was very sensitive. For example, on the ninth day of exposure to mixtures with $40 \mathrm{ppbV}$ of each pollutant, growth was significantly increased, but this benefit no longer existed by the fourteenth day: on the twenty-fourth day, there was a significant $22 \%$ decrease in growth, compared with the controls growing in filtered air without added pollutants. Similarly, Pande and Mansfield (1985) have found that the growth of barley seedlings is significantly decreased within 2 weeks of being exposed to mixtures with $40 \mathrm{ppbV}$ of both $\mathrm{SO}_{2}$ and $\mathrm{NO}_{2}$.

Clearly, there is a need for caution when considering these relationships, a requirement emphasized by the large amount of variation in the assessments of data drawn from different sources and analysed by Mansfield and Freer-Smith (1981), Bell (1982) and Roberts (1984). However, as shown by Whitmore, the task is not hopeless but extrapolations should not be made until an appropriate series of experiments have been made in a wide range of environmental conditions using different species and including fluctuating, and possibly intermittent, doses of $\mathrm{SO}_{2}$ and/or $\mathrm{NO}_{2}$ and $\mathrm{O}_{3}$.

In 1982, Heck et al. published some of the first season's results from the National Crop Loss Assessment Network in the United States. They obtained many significant linear regressions showing that the ozone sensitivities of different crops varied. For instance:

$$
\begin{array}{rlrl}
Y & =1065.7-5678 X & & \text { lettuce cv Empire } \\
\text { and } Y & =16.8-31 X & & \text { kidney bean } c v \\
& \text { California light red }
\end{array}
$$

where $Y=$ yield in $\mathrm{g}$ plant ${ }^{-1}$ and $X=$ seasonal $7 \mathrm{~h} \mathrm{day}^{-1}$ mean $O_{3}$ concentrations.

In discussing the relevance of their data, Heck and his colleagues pointed out that the results describe what happened with a limited range of crops during one season with its own unique weather pattern. 


\section{INFLUENCE OF OTHER BIOTIC AND ABIOTIC FACTORS ON THE RESPONSES OF PLANTS TO ATMOSPHERIC POLLUTANTS}

In separating and analysing the effects of environmental factors on the responses of plants to air pollutants, Jones and Mansfield (1982) found that timothy grass was particularly sensitive to $\mathrm{SO}_{2}$ in poor light conditions, a report agreeing with observations made by Bell et al. (1979) that grasses were noticeably sensitive to $\mathrm{SO}_{2}$ when growing slowly during winter.

During the winter, there is also evidence that atmospheric pollutants alter crop sensitivity to frost. Both Baker et al. (1982) and Davidson and Bailey (1982) have found that $\mathrm{SO}_{2}$ can increase frost damage to winter-sown cereals. Whereas more than $50 \%$ of plants survived overnight temperatures of $-8.8^{\circ} \mathrm{C}$ in unpolluted atmospheres, fewer were able to survive when the atmosphere also contained $87 \mathrm{ppbV} \mathrm{SO}_{2}$.

Despite the former widespread absence of black spot of roses and tar spot of sycamore (Acer pseudoplatanus) caused by Diplocarpon rosae and Rhytisma acerinum respectively, it seemed that attacks by most primary plant pathogens were only restricted by large concentrations of pollutants (see Heagle 1973). New evidence suggests that this deduction may be erroneous. Instead, it seems that some primary pathogens are controlled by continuous exposures to relatively small concentrations. There is also increasing evidence that pollutants, notably $\mathrm{SO}_{2}$, may increase the population densities of some insect pests (Fluckiger et al. 1978; Port \& Thompson 1980; Dohmen et al. 1984). 


\section{PLANT LOSSES IN FIELD CONDITIONS ATTRIBUTABLE TO ATMOSPHERIC POLLUTANTS}

In the study of plant diseases caused by bacterial, fungal and viral pathogens, it has been the custom to follow the procedures implied by Koch's postulates and attempt to show that a pathogen CAN cause disease. If this were successfully accomplished, it would then be appropriate to determine the extent and severity of the disease. Despite the vast amount of work that has been done with pollutants, the study of damage done by them in the field, in the conditions in which we find ourselves today, is only just beginning. Mostly, we are not concerned with the large ground-level concentrations of $\mathrm{SO}_{2}$ and $\mathrm{NO}_{\mathrm{x}}$ that were responsible, before the introduction of the Clean Air Acts (1956), for the death of trees in urban areas and in the environs of smelters, the replacement of sensitive, by tolerant, species of lichens and the loss of Sphagnum species in bogs as in the Pennines, UK. But, that having been said, the rapidly increasing vehicular emissions of $\mathrm{NO}_{x}$ noted in some countries (from 1.3 to 2.3 million tonnes between 1965 and 1980 in the Federal Republic of Germany), which, with hydrocarbons and sunlight, act as ozone precursors, are worrying - they may lead to the production of concentrations of ozone able to cause acute damage.

On balance, and in contrast to the problems related to forest dieback, agriculturists are concerned to identify the extent of chronic damage. In addition to explaining processes and mechanisms, it is hoped that fundamental studies done in controlled conditions will enable quantitative estimates of damage in the field. Bearing in mind the interplay between daily and seasonally changing mixtures of different pollutants, the different responses of species and cultivars, and of crops/stands at different stages of development, the influence of weather (frost and drought) and the interactions with pests and pathogens, it is virtually impossible to make authoritative extrapolations. Instead, estimates of growth decreases and yield losses must be sought from experiments done in conditions as nearly as possible similar to those encountered in 'the field'. Hence the present-day interest in field fumigation systems and arrays of open-top chambers (Baker et al. 1982; Colvill et al. 1983; Thompson et al. 1976).

Three series of open-top chamber experiments stand out, those done by Heggestad et al. (1980), Buckenham et al. (1982) and Heck et al. (1982). Heggestad and his colleagues in North Carolina and Maryland, USA, studied the responses of 2 cultivars of snap beans to filtration when grown in ambient atmospheres with appreciable amounts of ozone, but very little $\mathrm{SO}_{2}$. They found that filtration consistently increased yields from year to year, the yields, averaged for 5 years, of the $\mathrm{O}_{3}$-tolerant cultivar Astro increasing by $4.5 \%$ from 
$51.4 \mathrm{~g}^{\text {to }} 53.7 \mathrm{~g} \mathrm{plant}^{-1}$; those of the sensitive cultivar BBL 290 increased by $15.0 \%$ from $50.6 \mathrm{~g}$ to $58.2 \mathrm{~g} \mathrm{plant}^{-1}$ (Table 2). On average (3 seasons), Buckenham et al. found that the yields of spring barley, in an area of the UK with seasonal $\mathrm{SO}_{2}$ and hydrogen fluoride concentrations of 18-22 and $1.0 \mathrm{ppbV}$ respectively, were $32 \%$ (grain) and $54 \%$ (straw) larger in filtered than in unfiltered chambers. Heck et al. recorded $15 \%$ (soya bean), $25 \%$ (peanut), $28 \%$ (turnip), 23\% (lettuce), 7\% (kidney bean) losses attributable to ambient atmospheres with a seasonal $7 \mathrm{~h}^{\text {day }^{-1}}$ mean of $60 \mathrm{ppbV}$.

Table 2.

Effects of filtering ambient atmospheres on yields of fresh pods ( $\mathrm{g} \mathrm{plant}{ }^{-1}$ ) produced by 2 cultivars of snap beans (Phaseolus vulgaris) grown in open-top chambers in an area of the USA with appreciable summer concentrations of atmospheric ozone (Heggestad et al. 1980)

\begin{tabular}{lcccc}
\hline & \multicolumn{2}{c}{$\mathrm{O}_{3}$-tolerant 'Astro' } & \multicolumn{2}{c}{$\mathrm{O}_{3}$-sensitive BBL 290 } \\
& Non-filtered & Filtered & Non-filtered & Filtered \\
\hline 1972 & 49.7 & 45.1 & 43.8 & 55.6 \\
1973 & 64.4 & 72.4 & 64.1 & 72.7 \\
1974 & 60.3 & 62.2 & 64.4 & 72.8 \\
1975 & 27.7 & 27.7 & 35.3 & 39.3 \\
1976 & 55.1 & 61.1 & 45.3 & 50.7 \\
Mean & 51.4 & 53.7 & 50.6 & 58.2 \\
\hline \% increase attributable & \multicolumn{4}{c}{$15.0 \%$} \\
to air filtration & $4.5 \%$ & & & \\
\hline
\end{tabular}

In themselves, some of these decreases are appreciable, but how much care was taken to minimize the differences between the physical environment of the chambers and that in the 'field'? Would the environmental differences increase or decrease pollution sensitivity? If these problems are resolved satisfactorily, would it be possible to extrapolate so as to obtain estimates of regional losses? To do this in a rational manner it seems essential to assess the effects of ambient pollution in 'habitats' (locations) selected using 2 strata, their (i) pollution, and (ii) physical environments - the task for the immediate future.

In considering the extent of damage done by pollutants, it should be remembered that present-day varieties are likely to have some tolerance to ambient pollution, an inevitable consequence of selecting good performers from trials in the field. In the absence of historical data, it is conceivable that varieties may have some tolerance to $\mathrm{SO}_{2}$ and $\mathrm{NO}_{\mathrm{x}}$ but less so in relation to ozone, a newer and possibly intensifying problem.

As has been shown in the literature, varying degrees of $\mathrm{SO}_{2}$ tolerance have been identified in Geranium carolinianum and a range of grasses. By analogy 
with the selection of resistance to pathogens, tolerance to pollution may incur a penalty for growth made in the absence of pollution. This being so, it would seem appropriate for plant breeders to be made aware of the need to reconsider the appropriateness of present-day varieties for the future. 


\section{REFERENCES}

Amundson, R. G. \& Maclean, D. C. 1982. Influence of oxides of nitrogen on crop growth and yield: an overview. In: Air pollution by nitrogen oxides, edited by T. Schneider \& L. Grant, 501-510. Amsterdam: Elsevier Scientific.

Anderson, L. S. \& Mansfield, T. A. 1979. The effects of nitric oxide pollution on the growth of tomato. Environ. Pollut., 20, 113-121.

Ashmore, M. R. 1984. Effects of ozone on vegetation in the United Kingdom. In: The evaluation and assessment of the effects of photochemical oxidants on human health, agricultural crops, forestry, materials and visibility, edited by P. Grennfelt, 92-104. Gothenburg: Swedish Environmental Research Institute.

Ashmore, M. R. \& Onal, M. 1984. Modification by sulphur dioxide of the responses of Hordeum vulgare to ozone. Environ. Pollut. A, 36, 31-43.

Baker, C. K., Unsworth, M. H. \& Greenwood, P. 1982. Leaf injury on wheat plants exposed in the field in winter to $\mathrm{SO}_{2}$. Nature, Lond., 299, 149-151.

Bell, J. N. B. 1982. Sulphur dioxide and the growth of grasses. In: Effects of gaseous pollutants in agriculture and horticulture, edited by M. H. Unsworth \& D. P. Ormrod, 225-246. London: Butterworth.

Bell, J. N. B., Rutter, A. J. \& Relton, J. 1979. Studies of the effects of low levels of $\mathrm{SO}_{2}$ on the growth of Lolium perenne L. New Phytol., 83, 627-643.

Black, V. J. \& Unsworth, M. H. 1979. Effects of low concentrations of sulphur dioxide on net photosynthesis and dark respiration of Vicia faba. J. exp. Bot., 30, 473-483.

Buckenham, A. H., Parry, M. A. J. \& Whittingham, C. P. 1982. Effects of aerial pollutants on the growth and yield of spring barley. Ann. appl. Biol., 100, 179-187.

Cape, J. N. 1984. The importance of solution equilibria in studying the effects of sulphite on plants. Environ. Pollut. A, 34, 259-274.

Colvill, K. E., Bell, R. M., Roberts, T. M. \& Bradshaw, A. D. 1983. The use of open-top chambers to study the effects of air pollutants in particular $\mathrm{SO}_{2}$ on the growth of ryegrass Lolium perenne $\mathrm{L}$. Environ. Pollut., 31, 35-55.

Cowling, D. W., Jones, L. H. P. \& Lockyer, D. R. 1973. Increased yield through correction of sulphur deficiency in ryegrass exposed to sulphur dioxide. Nature, Lond., 243, 479-480.

Cowling, D. W. \& Koziol, M. J. 1982. Mineral nutrition and plant response to air pollutants. In: Effects of gaseous air pollutants in agriculture and horticulture, edited by M. H. Unsworth \& D. P. Ormrod, 349-375. London: Butterworth.

Davidson, A. W. \& Bailey, I. F. 1982. $\mathrm{SO}_{2}$ pollution reduces the freezing resistance of ryegrass. Nature, Lond., 297, 400-402.

Dohmen, G. P., McNeill, S. \& Bell, J. N. B. 1984. Air pollution increases Aphis fabae pest potential. Nature, Lond., 307, 52-53.

Evans, L. S., Dimitriadis, L. \& Hinkley, D. A. 1984. Seed protein quantities of field-grown soybeans exposed to simulated acidic rain. New Phytol., 97, 71-76.

Evans, L. S., Lewin, K. F., Patti, M. J. \& Cunningham, E. A. 1983. Productivity of field-grown soybeans exposed to simulated acidic rain. New Phytol., 93, 377-388.

Fluckiger, W., Oertli, J. J. \& Baltensweiler, W. 1978. Observations of an aphid infestation on hawthorn in the vicinity of a motorway. Naturwissenschaften, 65, 654-655.

Fowler, D. 1984. Transfer to terrestrial surfaces. Phil. Trans. R. Soc. Lond. B, 305, 281-297.

Fowler, D. \& Cape, J. N. 1982. Air pollutants in agriculture and horticulture. In: Effects of gaseous pollutants in agriculture and horticulture, edited by M. H. Unsworth \& D. P. Ormrod, 3-26. London: Butterworth.

Fowler, D. \& Cape, J. N. 1984. On the episodic nature of wet deposited sulphate and acidity. Atmos. Environ., 18, 1859-1866. 
Heagle, A. S. 1973. Interactions between air pollutants and plant parasites. A. Rev. Phytopathol., 11, 365-388.

Heath, R. L. 1980. Initial events in injury to plants by air pollutants. A. Rev. Pl. Physiol., 31, 395-431.

Heck, W. W., Taylor, O. C., Adams, R., Bingham, G., Miller, J., Preston, E., \& Weinstein, L. H. 1982. Assessment of crop loss from ozone. J. Air Pollut. Control Ass., 32, 353-361.

Heggestad, H. E., Heagle, A. S., Bennett, J. H. \& Koch, E. J. 1980. The effects of photochemical oxidants on the yield of snap beans. Atmos. Environ., 14, 317-326.

Jacobson, J. S. 1982. Ozone and the growth and productivity of agricultural crops. In: Effects of gaseous air pollutants in agriculture and horticulture, edited by M. H. Unsworth \& D. P. Ormrod, 293-304. London: Butterworth.

Jacobson, J. S. \& Troiano, J. J. 1983. Development of dose-response functions for effects of acidic precipitation on vegetation. Water Qual. Bull, 8, 67-71 \& 109.

Jones, T. \& Mansfield, T. A. 1982. The effects of $\mathrm{SO}_{2}$ on growth and development of seedlings of Phleum pratense under different light and temperature environments. Environ. Pollut. A, 27, 57-71.

Koziol, M. J. 1984. Interactions of gaseous pollutants with carbohydrate metabolism. In: Gaseous air pollutants and plant metabolism, edited by M. J. Koziol \& F. R. Whatley, 251-273. London: Butterworth.

Koziol, M. J. \& Whatley, F. R., eds. 1984. Gaseous air pollutants and plant metabolism. London: Butterworth.

Last, F. T., Fowler, D. \& Freer-Smith, P. H. 1984. Die Postulate von Koch und die Luftverschmutzung. Forstwiss. ZentBI., 103, 28-48.

Mansfield, T. A. \& Freer-Smith, P. H. 1981. Effects of urban air pollution on plant growth. Biol. Rev., 56, 343-368.

Mudd, J. B., Banerjee, S. K., Dooley, M. M. \& Knight, K. L. 1984. Pollutants and plant cells: effects on membranes. In: Gaseous air pollutants and plant metabolism, edited by M. J. Koziol \& F. R. Whatley, 105-116. London: Butterworth.

Ormrod, D. P. 1982. Air pollutant interactions in mixtures. In: Effects of gaseous air pollutants in agriculture and horticulture, edited by M. H. Unsworth \& D. P. Ormrod, 307-331. London: Butterworth.

Pande, P. C. \& Mansfield, T. A. 1985. Responses of spring barley to $\mathrm{SO}_{2}$ and $\mathrm{NO}_{2}$ pollution. Environ. Pollut. A, 38, 87-97.

Parry, M. A. J. \& Whittingham, C. P. 1984. Effects of gaseous air pollutants on stromal reactions. In: Gaseous air pollutants and plant metabolism, edited by M. J. Koziol \& F. R. Whatley, 161-168. London: Butterworth.

Port, G. R. \& Thompson, J. R. 1980 . Outbreaks of insect herbivores on plants along motorways in the United Kingdom. J. appl. Ecol., 17, 649-656.

Reinert, R. A., Heagle, A. S. \& Heck, W. W. 1975. Plant responses to pollutant combinations. In: Responses of plants to air pollution, edited by J. B. Mudd \& T. T. Kozlowski, 159-177. New York: Academic Press.

Roberts, T. M. 1984. Long-term effects of sulphur dioxide on crops: an analysis of dose-response relations. Phil. Trans. R. Soc. Lond. B, 305, 299-316.

Roberts, T. M., Darrall, N. M. \& Lane, P. 1983. Effects of gaseous air pollutants on agriculture and forestry in the UK. Adv. appl. Biol., 9, 1-142.

Thompson, C. R., Kats, G. \& Cameron, J. W. 1976. Effects of ambient photochemical oxidants on growth yield and ear characteristics of two sweet corn hybrids. J. environ. Qual., 5, 410-412.

Wellburn, A. R. 1982. Effects of $\mathrm{SO}_{2}$ and $\mathrm{NO}_{2}$ on metabolic function. In: Effects of gaseous air pollutants in agriculture and horticulture, edited by M. H. Unsworth \& D. P. Ormrod, 169-187. London: Butterworth.

Wellburn, A. R. 1984. The influence of atmospheric pollutants and their cellular products upon photophosphorylation and related events. In: Gaseous air pollutants and plant metabolism, edited by M. J. Koziol \& F. R. Whatley, 203-221. London: Butterworth.

Whitmore, M. E. 1985. Relationship between dose of $\mathrm{SO}_{2}$ and $\mathrm{NO}_{2}$ mixtures and growth of Poa pratensis. New Phytol., 99, 545-553.

Whitmore, M. E. \& Mansfield, T. A. 1983. Effects of long-term exposures to $\mathrm{SO}_{2}$ and $\mathrm{NO}_{2}$ on $P O a$ pratensis and other grasses. Environ. Pollut. A, 31, 217-235. 
Zeevart, A. J. 1974. Induction of nitrate reductase by $\mathrm{NO}_{2}$. Acta bot. neerl., 23, 345-346.

Zeevart, A. J. 1976. Some effects of fumigating plants for short periods with $\mathrm{NO}_{2}$. Environ. Pollut., 11, 97-108.

Ziegler, I. 1975. The effects of $\mathrm{SO}_{2}$ pollution on plant metabolism. Residue Rev., 56, 79-105. 

ISBN 0904282902 